\title{
British women of the nineteenth and early twentieth centuries who contributed to research in the chemical sciences
}

\author{
MARY R.S. CREESE*
}

Apart from a few outstanding people from before $1850,{ }^{1}$ British women of the nineteenth and early twentieth centuries who published work in the chemical sciences have not received much attention so far. The university-trained women who, from about 1880 onwards, authored or co-authored an increasing number of original research contributions have been largely ignored, and their names are for the most part omitted from biographical reference works and science histories. There are several works describing the changes and developments in university-level education for women during this period, ${ }^{2}$ but these are not specially concerned with science education or with the careers of individuals.

This overview focuses mainly on a small, élite subsection of the first generation of women graduates, those who were authors or co-authors of original work in the chemical sciences. Who were they, where did they work, what did they succeed in contributing, and to what was their success or lack of it due? These basic questions are still outstanding. I have tried here to provide some of the answers for the group of women whose first published research appeared before 1906. This includes those who were active during the first twenty-five years of noticeable involvement of women in scientific work, before the post-1905 period of rather rapid increase in women's publication rate (see Figure 1). The

* 1650 Cambridge Road, Lawrence, Kansas 66044, USA. This study was supported by the National Science Foundation, Washington, DC, Grant No. DIR-8907758, and by the University of Kansas General Research Fund, allocation no. 3693-xx-0038.

1 See Elizabeth Chambers Patterson, Mary Somerville and the Cultivation of Science, 1815-1840, The Hague, 1983 ; Eva V. Armstrong, 'Jane Marcet and her "Conversations on Chemistry" , Journal of Chemical Education, (1938), 15, pp. 53-7; J. K. Crellin, 'Mrs. Marcet's "Conversations on Chemistry”, ibid. (1979), 56, pp. 459-60; Marilyn Bailey Ogilvie, Women in Science. Antiquity through the Nineteenth Century, Cambridge, Mass., 1986, pp. 89-90, 125-7, 161-6.

2 See Margaret J. Tuke, A History of Bedford College for Women, 1849-1937, London, 1939; Rita McWilliams-Tullberg, Women at Cambridge. A Men's University-Though of a Mixed Type, London, 1975 ; A. Gardner, A Short History of Newnham College, Cambridge, 1921; Mary Agnes Hamilton, Newnham. An Informal Biography, London, 1936; Barbara Stephen, Girton College. 1869-1932, Cambridge, 1933 and Emily Davies and Girton College, London, 1927; Roy MacLeod and Russell Moseley, 'Fathers and daughters: Reflections on women, science and Victorian Cambridge', History of Education, (1979), 8, no. 4, pp. 321-33; Mabel Tylecote, The Education of Women at Manchester University 1883 to 1933, Manchester, 1941; Vera Brittain, The Women at Oxford, New York, 1960; Muriel St Clare Byrne and Catherine Hope Mansfield, Somerville College, 1879-1921, Oxford, 1922?; Gemma Bailey, Lady Margaret Hall. A Short History, London, 1923. 


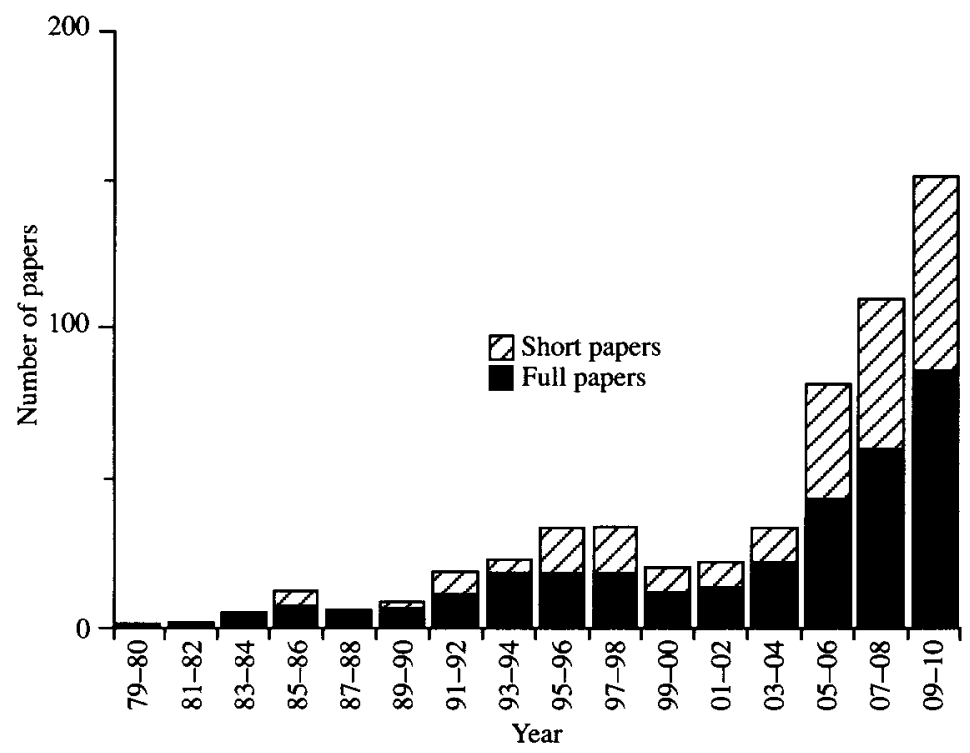

Figure 1. Number of publications authored or co-authored by British women chemists, 1879-1910, in two-year clusters. Data were obtained by counting papers by women listed in the London Chemical Society decennial indices, 1873-1912 (see note 103 below).

extent of participation by the members of this group varies from a modest contribution of one or two papers to a substantial body of work. Several of those mentioned were at the beginning of productive careers at my cut-off date, while others can be more definitively classed as belonging to the earliest group of university-trained researchers. To permit a somewhat fuller examination I have also given a brief indication of the work of a few distinguished women who, though students before 1906, first published during the following six-year period. The people discussed include the ablest and most prominent of the British women working in the chemical sciences at the time, the female counterparts of the top-ranking male academic research scientists. Whether or not their formal training was in chemistry in its present relatively narrow meaning, or in physiology/biochemistry or physics is of less consequence, for this study, than the research contributions they later made.

As introduction I mention the work of three early women from the period 1794 to 1846. The main part of the paper describes the members of three groups of women researchers active in the chemical sciences in the late nineteenth and early twentieth centuries: the Cambridge women, the graduates of the London colleges, and a few outstanding women graduates from other locations. This leads to and is the basis of a comparison of the achievements of women who worked in traditional areas of chemistry with those of women biochemists and a few notable women botanists and geologists of the same period. I end with some possible explanations for the relative lack of success of the chemists as independent researchers, and with a short discussion of the special position of Cambridge in the education of outstanding turn-of-the-century British women scientists. 


\section{INTRODUCTION: SOME EARLY 'GENTLEWOMEN' SCIENTISTS WHO MADE CONTRIBUTIONS TO CHEMISTRY}

Of the few British women from the early part of the nineteenth century whose contributions to the physical sciences are now fairly well documented, two, Jane Marcet and Mary Somerville, made notable contributions to chemistry. ${ }^{3}$ Both were largely selfeducated people who were able to stay abreast of current research through social connections with the London scientific circle of the time. They were both commentators whose aim was to make current scientific theories intelligible to the uninitiated, and they were outstandingly successful as pioneers in expository scientific writing. Somerville's On the Connection of the Physical Sciences, with ten editions between 1834 and 1877, is probably the first broad, non-specialist account of fundamental research in the physical sciences, including chemistry. ${ }^{4}$ Jane Marcet's two-volume Conversations on Chemistry ran to sixteen British editions and was used as a textbook for fifty years in Britain and the USA. A third woman, Elizabeth Fulhame, ${ }^{5}$ working in the last decade of the eighteenth century, carried out what was probably the first notable independent research in chemistry by a woman in the modern era. Searching for a practical method for depositing thin layers of metal on cloth and paper, she started a study which, over several years, developed into a remarkable investigation of the reduction of metallic salts with hydrogen and other reducing agents. Her report of her work, and her ideas about its implications for the still current debate on the phlogiston theory, appeared in $1794 .{ }^{6}$ It was favourably reviewed in Annales de Chimie in $1798,{ }^{7}$ and would be discussed again, over 100 years later, when it was pointed out that many of Fulhame's findings on the role of oxygen in combustion were more than once rediscovered during the nineteenth century. ${ }^{8}$

\section{THE TRANSITION TO UNIVERSITY TRAINING}

There is no apparent connection between these few exceptional early women scientists and

3 See Patterson, op. cit (1), Armstrong, op. cit (1) and Ogilvie, op. cit. (1).

4 Somerville's most celebrated work was The Mechanism of the Heavens, London, 1831, her annotated translation of Laplace's Méchanique Céleste. For this she wrote a preface, also published separately as $A$ Preliminary Dissertation on the Mechanism of the Heavens, London, 1832, which introduced the reader to the mathematics necessary for understanding the main work. She also published three papers reporting her experiments on the effects of solar radiation: 'On the magnetizing power of the more refrangible solar rays', Philosophical Transactions, (1826), pt 2, pp. 132-9, Annales de Chimie, (1826), 31, pp. 393-400; 'Expériences sur la transmission des rayons chimiques du spectre solaire, à travers différentes milieux', Comptes rendus de l'Académie des Sciences, (1836), 3, pp. 473-6, New Philosophical Journal, Edinburgh (1837), 22, pp. 180-3; 'On the action of the rays of the spectrum upon vegetable juices', Philosophical Transactions, (1846), pp. 111-21.

5 Ogilvie, op. cit. (1), pp. 89-90; Derek A. Davenport and Kathleen M. Ireland, 'The ingenious, lively and celebrated Mrs Fulhame, and a dyer's hand', Bulletin for the History of Chemistry, (1989), No. 5, pp. 37-42; J. R. Partington, A History of Chemistry, 4 vols., London, 1962, iii, pp. 708-9.

6 Mrs Fulhame, An Essay on Combustion, with a View to a new Art of Dyeing and Painting. Wherein the Phlogistic and Antiphlogistic Hypotheses are Proved Erroneous, London, 1794 (German tr. A. G. W. Lentin, Göttingen, 1798; American edn Philadelphia, 1810).

7 J.F. Coindet, 'De l'ouvrage de Mme Fulhame, intitulec: An Essai on Combustion, etc. Essai sur la combustion avec des vues...', Annales de Chimie, (1798), 26, pp. 58-85.

$8 \mathrm{~J}$.W. Mellor, 'History of the water problem (Mrs Fulhame's theory of catalysis)', Journal of Physical Chemistry, :1903), 7, pp. 557-67. 
those who, in increasing numbers, became active in chemical research in the 1880 s and 1890 s. There was no gradual increase in women's participation in research from the time of Somerville to the last decades of the century. Instead there is a gap of almost thirty years in which virtually no references to journal publications in the chemical sciences by British women appear in the scientific indices. ${ }^{9}$ The fact that not even the few exceptional women were taking any visible part in chemical work during this period is doubtless related to the increasing trend towards more standardized technical training as prerequisite for any such participation, coupled with the exclusion of women from the universities. It meant, however, that the women chemists of the 1880s and 1890s who finally did make their way into the research laboratories were breaking entirely new ground; they had to find places in an already well-established and exclusively male environment, and any prior participation in chemistry by women in past decades or at earlier times had little relevance to the practical problems they faced. As scientists they are more an offshoot of the nineteenth-century male-orientated educational system (and at the same time a small section of it) than a link in any tradition of 'women in science'. The change for women scientists from the pre- 1880 period to the late nineteenth century is especially noticeable in chemistry. ${ }^{10}$

Landmarks of the new era for women in scientific training and research in Britain were the founding of Girton and Newnham Colleges at Cambridge in 1869 and 1871, the opening of University of London degrees to women in 1878, the official opening of the Tripos examinations to women at Cambridge in 1881, and the great improvement in scientific training at Bedford College for women in the 1880s. ${ }^{11}$ These events were quickly reflected in the appearance of publications by women in the scientific journals. From 1880 until about 1900 women gradually established their presence as research workers in the chemical sciences and set the stage for the rapid increase in their research productivity that took place after the turn of the century. The steady increase in the number of their publications after 1905 is remarkable (see Figure 1).

The earliest research by women came mainly from Cambridge and the London colleges, especially University College, and, after 1900, the Royal College of Science (later the Imperial College of Science and Technology). Research from these three institutions accounted for about 21,16 , and 13 per cent respectively of the papers published by women in the chemical sciences before 1906. Early contributions from women at other institutions included those from students of T.E. Thorpe at Yorkshire College, Leeds, from coworkers of Sydney Young and Sir William Ramsay at University College, Bristol, and from women at Mason Science College (later the University of Birmingham), Dover College and University College, Dundee (see Appendix 1).

9 An examination of the Royal Society's Catalogue of Scientific Papers, 1800-1900, 19 vols., Cambridge, 1867-1925, i-xii, uncovered one paper written by a British woman on a chemical topic during the period 1846-80, namely Margaret H. Marshall's, 'Experiments and investigations as to the influence exerted over some minerals by animal and vegetable matter, under certain conditions', Proceedings of the Royal Society of Edinburgh, (1851), 2, pp. $58-61$.

10 As contrast, in both botany and geology the number of publications by British women showed a noticeably more gradual increase over the course of the century; my unpublished data.

11 Tuke, op. cit. (2), esp. pp. 18, 127-8, 138-9; McWilliams-Tullberg, op. cit. (2), pp. 70-84. Women at Cambridge were permitted to take the Tripos examinations informally throughout the 1870 s. Their names were omitted from official pass lists. 
The women worked in all branches of the field, from biochemistry to physical chemistry. There was no marked emphasis on a single subfield as was the case with their American contemporaries who, like the majority of American chemists of the period, were concentrated in applied analytical chemistry. ${ }^{12}$ However, biological chemistry and physical chemistry were prominent in the earliest of the British women's work, and biological chemistry was to remain so at Cambridge for several decades. In the London colleges, inorganic and physical chemistry were most important in the 1880s and 1890s, and organic chemistry overwhelmingly so after 1900 .

\section{CAMBRIDGE}

Several circumstances at Cambridge combined to make it the single most important place in Britain for research by women in the chemical sciences from the 1880 s until well after the turn of the century. Although the existence of Girton and Newnham Colleges was not formally recognized by the university, the women students from both were, from the beginning, able to attend University lectures provided they had the personal consent of the lecturers. George Liveing, university professor of chemistry and a strong advocate of education for women, J.W. Hicks, another chemist, and Sir Michael Foster, the physiologist, were among the enlightened dons who helped the women students gain access to science lectures. Liveing had advised an emphasis on chemistry in the natural science class taught by Hicks at Hitchin College, the forerunner of Girton, and he arranged for women students to attend his own chemistry lectures by $1873 .{ }^{13}$ Women were not granted degrees, however, only certificates of proficiency, and, given the possibilities offered by London University after 1878 , it might be thought remarkable that so many of the most able continued to choose Cambridge. Rita McWilliams-Tullberg has pointed out that there were 'strong academic grounds for their preference, for the old universities still trained and employed the finest men teachers to whom the women students could hope to have access'. ${ }^{14}$ The perceived superior quality of the overall educational experience at Cambridge clearly counterbalanced the attraction of the London degree. ${ }^{15}$ Furthermore, women were accepted at Girton and Newnham only if they were candidates for the Tripos (honours) examinations. ${ }^{16}$ Consequently the Cambridge women formed an élite group of especially capable students.

Yet other factors influenced the overall development of the women students and their instructors at Girton and Newnham Colleges. The restrictions under which they were

12 My unpublished data.

13 See letter from Emily Davies to Mme Bodichon, September 6, 1873, quoted by Stephen, Emily Davies and Girton College, op. cit. (2), p. 282; also MacLeod and Moseley, op. cit. (2), p. 326.

$14 \mathrm{McW}$ illiams-Tullberg, op. cit. (2), p. 143. The early women students at Cambridge came predominantly from the middle classes, especially from industrial, commercial, and professional families of the north of England and London and the south-east (see MacLeod and Moseley, op. cit. (2), p. 329). These families had 'an unerring instinct for "quality" (McWilliams-Tullberg, op. cit. (2), p. 25), an attribute which the older universities, whose graduates continued to dominate public life in England at least until the First World War, were seen to embody.

15 Many Cambridge women students found themselves obliged to take the London degree as well in order to obtain the needed degree titles.

16 Candidates for ordinary degrees were not accepted at the women's colleges though, as in the case of the men, failure to meet the required standard in the honours examinations could result in a pass at the ordinary level; McWilliams-Tullberg, op. cit. (2), p. 222. 
obliged to function called for the development of considerable independence, initiative and determination. The partial isolation of the two women's colleges, resulting from the fact that they were not officially part of the university, was a deeply felt handicap for the women teachers especially. They were ineligible for funds for advanced work, barred from University prizes and scholarships which might have helped them financially, and heavily restricted in their use of the University library. ${ }^{17}$ The women students were likewise excluded from almost all financial assistance and indeed depended on the goodwill of the instructor for admission to University lectures and laboratories. As late as the 1920 s they were subject to considerable harassment from the men. Contemporary opinion indicates that opposition to their presence was strongest among the science and medical men. ${ }^{18}$

It is hardly surprising that, given the background of high aspirations and careful initial selection, followed by four years of character building in rigorous conditions, the women who came through Newnham and Girton Colleges were an exceptional group; among them were to be found the ablest women scientists of the time.

Of the various branches of chemistry, the one which most attracted the prominent Cambridge women from the early period was physiological chemistry. Some of the work they did might today be thought of as more physiology than chemistry, but to reclassify it here as such would risk imposing a late twentieth century view on what constitured the area of professional interest of the turn-of-the-century chemist/biochemist. In those days, 'liaison between physicists, chemists and biochemists was closer than it is, or can reasonably be expected to be today', and work of 'considerable importance and much chemical interest' was carried on at Cambridge in laboratories other than the University and College chemical laboratories. This was particularly the case in electrochemistry (done in the physics laboratory!, colloid chemistry, biochemistry and plant biochemistry. ${ }^{19}$ All of these were areas in which women included in this survey were active. ${ }^{20}$

The earliest of the notable Cambridge women biochemists/physiologists were Marion Greenwood and Mary Christine Tebb. Marion Greenwood ${ }^{21}$ (1862-1932) entered Girton College from Bradford Girls' Grammar School with an entrance scholarship in 1879 at the age of seventeen. She obtained Class I in both parts of the Natural Sciences Tripos (NST) examinations in 1882 and 1883, specializing in physiology in Part II, and at once became demonstrator in physiology to the women students of Newnham College. She held a Bathurst Studentship at Newnham and was the first winner of the Gamble Prize in 1888.

17 Stephen, Emily Davies and Girton College, op. cit. (2), p. 358, and McWilliams-Tullberg, op. cit. (2), p. 105. 18 Ibid., pp. 179-80. See also MacLeod and Moseley, op. cit. (2), pp. 330-1.

19 A. J. Berry and E. A. Moelwyn-Hughes, 'Chemistry at Cambridge from 1901 to 1910', Proceedings of the Chemical Society, (December 1963), pp. 357-63, esp. p. 357.

20 The inclusion of work from these border areas in the Chemical Society's indices of the chemical literature of the period further shows that it was considered part of chemistry (rather than physics or physiology) at the time. All of the work considered in this study was so indexed. Robert E. Kohler in, From Medical Chemistry to Biochemistry. The Making of a Biomedical Discipline, Cambridge, 1982, has discussed the great complexity of the interrelationship between chemistry and physiology and the new field of chemical physiology or biochemistry. The latter was in the process of developing from the two older disciplines in the last decade of the nineteenth century and the carly years of the twentieth.

21 See Stephen, Girton College, 1869-1932, op. cit. (2), p. 172, and W. H. B., 'Mrs G. P. Bidder', Nature, (1932), 130, pp. 689-90. 
An outstanding administrator and teacher, she was appointed head of the Balfour laboratory (the women's laboratory) in $\mathbf{1 8 9 0 . ~ A l o n g ~ w i t h ~ h e r ~ c o l l e a g u e ~ t h e ~ p l a n t ~ g e n e t i c i s t ~}$ Edith Saunders, she organized and taught the practical work in biology for women students until 1899, when she left to marry the biologist G. P. Bidder of Trinity College.

As one of those who belonged to the very first wave of women science graduates 'to break against the wall of established atritudes ', ${ }^{22}$ Marion Greenwood faced considerable opposition 'in those early days of hostility, touched as it was sometimes by a spice of active persecution':

At that time women were rare in scientific laboratories and their presence was by no means generally acceptable - indeed, that is too mild a phrase. Those whose memories go back so far will recollect how unacceptability not infrequently flamed into hostility. The woman student was rather expected to be eccentric in dress and manner; she was still unplaced, so far as the male in possession was concerned. ${ }^{23}$

Greenwood's research was carried out in Michael Foster's physiology laboratory. Although her early papers on glandular secretion reflected the interests of J. N. Langley, she quickly found her own area and published solid work on the role played by acid in protozoan digestion, and on the structural changes induced in the nuclei of protozoa by 'metabolic strain'. Her research ended with her marriage, but she continued her work in Girton College affairs and in civic organizations,

Mary Christine Tebb ${ }^{24}$ (1868-1953) studied at Bedford College, London (1882-87), and then at Girton College (1887-93), taking the NST examinations in 1890 and 1891 . She gained Class I in both parts, specializing in physiology in Part II. She held a Bathurst Studentship and served as assistant to Marion Greenwood from 1891 to 1893 . While at Cambridge she worked on enzymatic hydrolysis of complex carbohydrates, publishing three papers on the subject, and she continued in this area after moving to W. $\mathrm{H}$. Halliburton's Chemical Physiology Laboratory at King's College, London. Here she also undertook a series of investigations on the structure of protein fibres in connective tissue, work which brought her into a controversy about the nature of the protein, reticulin. Tebb's views and those of her opponent, the German chemist Sigfried, were not reconciled until much later, when laboratory techniques and the theories of physical chemistry had advanced sufficiently to grapple with the complexities of the questions involved. ${ }^{25}$ Between 1907 and 1910 she collaborated with the German-born chemist Otto Rosenheim, then lecturer in physiological chemistry at King's College, on the problem of whether the crystalline material 'protagon' isolated from brain was or was nor a single chemical compound. They co-authored ten papers on the subject and demonstrated that 'protagon' was a mixture. Considerable controversy followed, but their findings stood the test of time. Tebb married Rosenheim in 1910. She continued her research at the Physiological Laboratory at King's College until 1916, her work on cholesterol being supported by grants

22 MacLeod and Moseley, op. cit. (2), p. 331.

23 w. H. B., op. cit. (21), p. 689.

24 Girton College Register, 1869-1946, p. 47, and Girton College Review, Easter Term, 1953. I thank Ms Kate Perry, Archivist, Girton College, for giving me information abour Tebb.

25 See J. T. Edsall in The Origins of Biochemistry: A Retrospect on Proteins (ed. P. R. Srinivasan, J. S. Fruton and J. T. Edsall), New York, 1979, pp. 54-5. 
from the Royal Society. In the early 1920 s she joined her husband in the work of elucidating the chemical structure of spermine, research carried out in the laboratories of the Medical Research Council in Hampstead.

A third notable early physiologist/biochemist was Florence Margaret Durham ${ }^{26}$ (1869-1949), the daughter of a London surgeon. Her education followed a pattern similar to that of Christine Tebb. She went to Girton in 1888 after four years at Bedford College, and took both parts of the NST examination (1891 and 1892), specializing in physiology. After six years as a lecturer at Royal Holloway College, she returned to Cambridge in 1899 and was lecturer in physiology at Newnham College until 1910. Her biochemical studies on animal pigments, reported in 1904 and 1907, were carried out in the Balfour Laboratory. Many of her later publications resulted from her research in genetics done in collaboration with the botanist William Bateson at the John Innes Horticultural Institute in Merton between 1910 and 1914 . This work had considerable impact on the techniques of the study of heredity in both plants and animals. In 1917, following a period of war service as a hospital pathologist, she joined the staff of the Medical Research Council, and worked as a research scientist in pharmacology until her retirement in 1930.

Of the women research biochemists who completed the NST course before 1905, two of the most distinguished were Ida Smedley MacLean (1877-1944) and Muriel Wheldale Onslow (1880-1932). It is hardly a coincidence that both received their secondary education at King Edward VI High School for Girls, Birmingham, which at that time held the foremost position among girls' schools in England for science teaching. Under Edith Creak, a Newnham pioneer in the early 1870s, the school's science staff of three Newnhamites, A. C. Slater, L. Davison and J. Bingham, was responsible for a succession of science scholars who went to Newnham. ${ }^{27}$ Of these the first, and it has been said the most brilliant, was Ida Smedley. ${ }^{28}$ While still a schoolgirl she attended classes (then men's) in physiology in the medical department of Mason College, this being a year or two before the opening of new science laboratories gave King Edward's 'the best laboratories of any Girl's School in England'. ${ }^{29}$ She took the London Matriculation and Intermediate B.Sc. examinations from school, and was awarded a three-year Gilchrist Scholarship for an honours certificate with four distinctions in the Cambridge Higher Local Examinations. Clearly the influence of Newnham on her education started well before she went there in 1896. She obtained Class I in Part I of the NST examinations in 1898 and Class II in Part II (chemistry and physiology) in 1899. From 1901 to 1903 she held a Bathurst Studentship, doing postgraduate work under H.E. Armstrong at the Central Technical College,

26 Girton College Register, 1869-1946, p. 49, and Girton College Review, Michaelmas Term, 1949, p. 35. I thank Ms Kate Perry for providing information on Durham.

27 See Winifred I. Vardy, King Edward VI High School for Girls Birmingham 1883-1925, London, 1928, especially the Appendix, pp. 118-32; Marjory Stephenson, 'Muriel Wheldale Onslow (1880-1932)', Biochemical Journal, (1932), 26, pp. 915-16; M[ary] E. de R. E[pps], 'Ida Smedley MacLean', Newnham College Roll Letter (January 1945), pp. 50-1.

28 de R. E[pps], op. cit. (27). See also M. A. Whiteley, 'Ida Smedley MacLean. 1877-1944', Journal of the Chemical Society, (1946), Pr 1, pp. 65-7; Harriette Chick, Margaret Hume and Marjorie Macfarlane, War on Disease. History of the Lister Institute, London, 1971, pp. 164-6; Newnham College Register, 1896. I thank Miss Ann Phillips, Librarian, Newnham College Archives, for information about Smedley.

29 Vardy, op. cit. (27), p. 26. 
London. Her grant of $£ 10$ from the Chemical Society's Research Fund (17 December 1902) is probably the first such grant made to a woman chemist. ${ }^{30}$ She was demonstrator at Newnham from 1903 to 1906 while also carrying out research at the Davy-Faraday Research Laboratory of the Royal Institution. Her D.Sc. (London) was awarded in 1905, and in 1906 she became the first woman to be appointed to the staff of the Chemistry Department of the University of Manchester. During her four years there her research was in physical-organic chemistry, on the refractive power of unsaturated, aliphatic hydrocarbons and on the relation between chemical constitution and optical properties in aromatic diketones. The results were published in a series of papers between 1906 and 1911. In 1910, having been awarded one of the first Beit Memorial Research Fellowships, she went to the Lister Institute in London and began her investigations on the chemistry and metabolism of fats, work which was to continue for the rest of her life. She became a staff member of the Institute in 1932. During the First World War she worked at the Admiralty on various essential projects, including the large-scale production of acetone from starch by fermentation. She became a Fellow of the Institute of Chemistry in 1918. 'She was a fine chemist ${ }^{\text {'31 }}$ and her work on the processes of oxidation of fatty acids in vitro and on the pathways by which fat is synthesized from carbohydrate in living organisms were particularly important contributions to the field. Her research on the highly unsaturated fatty acids confirmed earlier conjectures on the crucial role played by these in animal metabolism. Working with very small quantities of material she also established the structure of one of the three 'essential fatty acids', arachidonic acid. About thirty papers on the fat metabolism work, some of it collaborative, appeared in the Biochemical Journal between 1920 and 1941. Her monograph, The Metabolism of Fat, published in 1943 as the first of Methuen's monographs in biochemistry, summarized her views on the field, in which she was by then an established authority.

In addition to her scientific work, Smedley played an important part in the advancement of the professional status of university women. She was one of the founders of the British Federation of University Women, and later the International Federation. From the start of the movement in 1907 she held high office, serving as the first Secretary and later (1929-35) as President. One of her special interests was the endowment of the Federation's International Fellowships for original research. She was also a leader in the struggle for admission of women to fellowship in the scientific societies, especially the Chemical Society. When the long-drawn-out effort for their admission to the latter finally succeeded in 1920 Ida Smedley MacLean was the first women to be formally admitted. She was later a Council Member (1931-34). Along with her sister, Constance Smedley Armfield, she was

30 The total amount awarded that year was $£ 230$ spread over seventeen people, making an average award of $£ 1310$ s. Smedley received similar awards in 1909 and 1910 of $£ 10$ and $£ 15$ respectively. A total of five women chemists received Chemical Society Research Fund grants during the period 1902-10. Besides Smedley they were Alice Emily Smith, Owens College Manchester and University College, Bangor (1905), Annie Homer, Newnham (1907, 1908), and Mary Elizabeth Dobson $(1909,1910)$ and Gertrude Maude Walsh (1910), both from Manchester University. See Research Fund Income and Expenditure Accounts, in reports of Annual General Meetings, Journal of the Chemical Society, Transactions, (1903), 83, p. 635; ibid. (1906), 89, p. 743; ibid. (1908), 93, p. 722; ibid. $\{1909,, 95$, p. 621 ; ibid. $\{1910,97$, p. 659 ; ibid. $(1911), 99$, p. 585.

31 Chick, Hume and Macfarlane, op. cit. (28), p. 165. 
active in the founding of the Lyceum Club for professional women. In 1913 she married her fellow biochemist at the Lister Institute, Hugh MacLean, who later became Professor of Medicine in the University of London at St Thomas's Hospital. They had two children. 'How she managed to hold three threads evenly in her hands, research, social work and home life, was a constant wonder even to those who knew her best. ${ }^{32}$

Muriel Wheldale entered Newnham College from King Edward's School, Birmingham, in $1900 .{ }^{33}$ She took both parts of the NST examinations with botany as principal subject. She held a Bathurst Studentship in 1904, followed by a Newnham College Fellowship in 1909, and she was assistant lecturer in botany at Newnham from 1906 to 1908 . As in Florence Durham's case, her work was strongly influenced by William Bateson, and her initial studies concerned the genetic pathways of the anthocyanin pigments in plants. She then proceeded to develop a chemical interpretation of the genetic data and her studies culminated in the publication in 1916 of her monograph, The Anthocyanin Pigments in Plants, which established her international reputation as a pioneer in the field of plant biochemistry. Her later research concerned the oxidase systems of the higher plants, and she also worked on practical problems relating to chemical changes occurring during ripening of fruits. Apart from three years (1911-14) at the John Innes Horticultural Institute, her working life was spent at Cambridge, her activities divided between the Botany School and the Biochemical Department, which, under the leadership of F. G. Hopkins, was then outstanding as one of the few university science departments in which women scientists were fully welcomed and their independent research encouraged and supported. ${ }^{34}$ Her lectures in plant biochemistry formed an important unit in the teaching of advanced botany. In 1927, at age forty-seven, she was appointed university lecturer in biochemistry, one of the first women to receive such an appointment. The first volume of her Principles of Plant Biochemistry appeared in 1931, one year before her death. In 1919 she had married Huia Onslow, a co-worker in the field of chemical genetics, and until his death in 1922 their work was closely related. Onslow's own considerable professional achievements in the face of extreme physical handicap owed much to the assistance of his wife.

Although Annie Homer's first published work did not appear until 1907, I include her here because her career followed a pattern that was remarkably similar to that of Ida Smedley. She went to Newnham College from King Edward's School, Birmingham, and took the NST examinations in 1904 and 1905 (Class I, chemistry, Part II). Like Smedley, she carried out her first research on spectral properties of organic compounds, and later moved to biochemistry, finding, as Smedley had done, a position at the Lister Institute which offered more scope for independent work. She held a Bathurst Studentship at Newnham in 1905 and thereafter several fellowships, including a Newnham College Fellowship and a Beit Research Fellowship. Between 1907 and 1910 she published eight papers describing her synthetic work in multicyclic aromatic systems and her subsequent investigations of their absorption spectra. Much of this research was done in collaboration with J. E. Purvis. She received a D.Sc. in 1910. At the Lister Institute throughout the First

32 de R. E[pps], op. cit. (27), p. 51.

33 Stephenson, op. cit. (27).

34 Derek Richter, 'Opportunities for Women in Science', in Women Scientists. The Road to Liberation (ed. Derek Richter), London, 1982, p. 7. 
World War she was involved in the critical project of antisera production for army use, and she published thirteen substantial single-author papers on this work, mainly in the Biochemical Journal and the Journal of Physiology. ${ }^{35}$

A fourth early Newnham College biochemist whose secondary education was at King Edward's School, Birmingham, was Edith Gertrude Willcock. She took the NST examinations in 1902 and 1904 (Class 1, physiology, Part II), and was awarded a Newnham Fellowship in 1905. She carried out early work on the effects of radiation on simple organisms and also collaborated with W. B. Hardy on protein studies. In joint research with F. G. Hopkins she investigated the role of individual amino acids in animal metabolism, demonstrating the 'essential' nature of some.

Of all the early Cambridge women biochemists, however, probably the most outstanding was Marjory Stephenson. She was a student at Newnham College from 1903 to 1906, and in 1919, following some years in London and war service with the Red Cross in France and Salonika, she returned to the Biochemistry Department at Cambridge. After early work on the fat soluble vitamins, Stephenson, at the urging of F. G. Hopkins, turned to the chemistry of bacteria, and it was she who was largely responsible for the founding in Britain of bacterial chemistry as a separate discipline within the general field of biochemistry. She was the first to explore systematically the physiology of microbes as biochemical systems responding constantly to changes in their chemical environment, and she laid the foundation for much of the later work in this area. Her more than forty publications appeared in the biochemical journals in a steady succession between 1911 and 1948, and her classic monograph, Bacterial Metabolism (1930), remained a standard for decades. She was elected a Fellow of the Royal Society in 1945 (the first woman in Division B), and she was President of the Society of General Microbiology in 1948, the year of her death. In 1947 she became a Reader in chemical microbiology at Cambridge, though she had lectured in advanced courses since 1925. At age forty-four (in 1929) she was appointed to the permanent scientific staff of the Medical Research Council at Cambridge; until then she had existed on annual grants and fellowships. In an obituary of Stephenson, Muriel Robertson remarked that, 'It is a curious reflection on the difficulties in the path of women scientists and perhaps also a sign of the distrust of a somewhat new subject that so original a worker should have been an annual grantee for so many years. ${ }^{36}$ Dorothy Needham, another slightly later Cambridge biochemist in Hopkins' group who became an FRS in 1948, touched on the same point: 'Looking back over my 45 years in research I find it remarkable, especially from the point of view of contemporary practice that, although a fully qualified and full-time investigator, I never received or even applied for, any substantive post. I simply existed on one research grant after another, devoid of position, rank or assured emolument.' She never had the 'self-respect which comes from a recognised and established position'. ${ }^{37}$ This was, however, a marked improvement over the

35 Chick, Hume and Macfarlane, op. cit. (28), pp. 124, 234. See also Vardy, op. cit. (27), pp. 120-2.

36 See p. 566 in Muriel Robertson, 'Marjory Stephenson (1885-1948)', Obituary Notices of Fellows of the Royal Society, (1949), 6, pp. 563-77.

37 Dorothy Needham, 'Women in Cambridge Biochemistry', in Richter (ed.), op. cit. (34), pp. 158-63, esp. p. 161. Kohler (op. cit. (20), p. 88) comments that in the 1930 s there was a certain amount of difficulty in Hopkins' Department with financial support, in part the 'normal problems of a large and extremely diverse group supported by a plethora of grants and fellowships and held together by "Hoppy's" gentle charisma'. Nevertheless, 'Dorothy Needham carried on her first-rate work on a third-rate salary ... and Marjory Stephenson was constantly having to beg for small sums...' 
position faced by outstanding women graduates twenty-five years previously. Other studies have pointed out that women coming out of the universities in the 1890s and around the turn of the century often undertook substantial periods of even unpaid work so as to be able to put their training to use in original research. ${ }^{38}$ With the struggle for equal access to scientific education still going on in the 1920s, the struggle for fair compensation and equal access to academic posts was so far in the future that, as Needham's remarks suggest, it had hardly even been contemplated by the leading women scientists themselves.

Of the early Cambridge women active in the chemical sciences only a few were not biochemists or did not move into biochemistry relatively early in their careers. Of these few the most notable were Eleanor Sidgwick and the two lecturers at Newnham and Girton Colleges, Ida Freund and Mary Beatrice Thomas.

In the early 1880s Eleanor Balfour Sidgwick $(1845-1936)^{39}$ carried out what was for a woman at that time a remarkable series of investigations in electrochemistry. She had grown up in a distinguished family, possessing considerable wealth. As a child she was interested in mathematics and she had some early instruction from her mother. Following the marriage in $\mathbf{1 8 7 1}$ of her younger sister to the physicist John Strutt (later Lord Rayleigh) she was able to continue her studies with guidance from him. Education for women and the new women's colleges at Cambridge University, where her brothers were undergraduates, were her other special interests. At the time of her own marriage in 1876 to Henry Sidgwick of Trinity College she was secretary to the Principal of Newnham and at the same time was assisting informally as a tutor in algebra while reading for the Cambridge Higher Local Examinations. She did not proceed to the Tripos examinations, feeling that that would interfere with the responsibilities for the further organization and functioning of Newnham College which she had assumed following her marriage. She was Treasurer of the College from 1876 to 1919, Vice-Principal in 1880 and Principal from 1892 to 1911. Her scientific work with her brother-in-law began in 1880. In 1879 Rayleigh had succeeded Clerk Maxwell at Cambridge in the new Chair of Experimental Physics. Eleanor Sidgwick first joined in his private laboratory work, but then found herself included in a more extensive programme of joint research involving the accurate determination of the e.m.f. of Clark cells and the electrochemical equivalent of silver, part of a big programme set up by Rayleigh to redetermine the three electrical standards. 'The fundamental,

38 See, for instance, Rosaleen Love, " "Alice in Eugenics-Land": feminism and eugenics in the scientific careers of Alice Lee and Ethel Elderton', Annals of Science, (1979), 30, 145-58. Alice Lee, a student of Karl Pearson at University College and one of the first women to receive a London D.Sc. (1901), continued her research in Pearson's statistics laboratory mostly on a voluntary basis while supporting herself as a lecturer at Bedford College. When ill-health forced her to retire and she was left impecunious, Pearson, in 1923, petitioned the Home Office for a $£ 70$ per annum Civil List pension for her, stating that ' $f e w$, if any, women workers of her period have accomplished as large a bulk of first class research as Dr Lee' (Pearson papers, 629; Love, note 45, p. 152). Lee's colleague, Ethel Elderton, a full-time member of the statistics laboratory staff, earned, in 1906, $£ 100$ per annum. A Research Fellow received $£ 250$ per annum, a salary considered acceptable for men. Despite Pearson's exceptionally strong commitment to equality for women it is clear from his correspondence that he considered such low-paid (or unpaid) posts ' well suited to a woman living with her family in London and keen on scientific work' (letter from Pearson to A. Cave, 25 November 1907, Pearson papers CID7 (1); Love, note 78, p. 157). For comparison, the post of assistant mistress in a school providing secondary education then paid on average about $£ 118$ per annum.

39 Ethel Sidgwick, Mrs Henry Sidgwick. A Memoir by her Niece, London, 1938. 
practical character of the work was after Mrs Sidgwick's own heart; but it was longdrawn-out, exact and trying'.40 She assisted Rayleigh and Arthur Schuster in taking the observations, and herself carried out and checked most of the computations involved. When Schuster moved to Manchester, Eleanor Sidgwick took over his part of the work. The results were published in two long joint papers in the Philosophical Transactions ${ }^{41}$ and in shorter notes in the Proceedings of the Royal Society.

Ida Freund ${ }^{42}$ lecturer in chemistry at Newnham College for more than twenty years, was born in Austria in 1863. She studied at the State School and the State Training College for Teachers, Vienna, before coming to Britain in 1881 at the age of eighteen. Entering Girton College in 1882, she took the NST examinations in 1885 and 1886 (Class I, chemistry and physics, Part II). For a year (1886-87) she lectured at the Cambridge Training College for Women, and then joined the staff of Newnham College, where after three years as demonstrator, she became lecturer in chemistry, the post she held until 1913. Ida Freund was a remarkable person. In her youth she had had a cycling accident and had lost a leg. However, though confined to an invalid chair, she ran the Newnham College Chemistry Laboratory until her retirement, at which time it was closed. She was an excellent organizer and teacher and an energetic supporter of science education for women. She was an Associate of Newnham from 1893 to 1913 and a Council member from 1896 to 1913. When awarded the Gamble Prize in 1903 she gave the money to Girton College and the Balfour Laboratory for the purchase of books and apparatus. The Ida Freund Memorial Fund subscribed after her death in 1914 provided further training opportunities for women teachers in the physical sciences. She published original work on the theory of solutions, a substantial paper appearing in $1909,{ }^{43}$ but her best known work was her textbook, The Study of Chemical Composition (1905), which remained a classic for many years.

Mary Beatrice Thomas went to Newnham College from King Edward's School, Birmingham, taking the NST examinations in 1897 and 1898. She held a Priestley Scholarship at Birmingham University in 1901, but subsequently returned to Cambridge, where she taught chemistry and served as Director of Studies in Natural Science at Girton College. Describing her early chemical training at Girton, Dorothy Needham remarked on the outstanding quality of Thomas's teaching and the rigorous experimental work she demanded in the College laboratory: 'It seemed that in the period at the end of the First World War the schemes followed in the Girton laboratory for experimental chemistry were incomparably better planned and organized than those available in the University Chemical Department, which then for the first time had replaced most of the separate College laboratories. This famous laboratory at Girton finally closed in 1935 when Miss

40 Ibid., p. 72.

41 Lord Rayleigh, FRS and Mrs H. Sidgwick, 'On the specific resistance of mercury', Philosophical Transactions, (1883), 174, pt 1, pp. 173-85; 'On the electrochemical equivalent of silver and the absolute electromotive force of Clark cells', ibid. (1884), 175, pp. 411-60.

42 Stephen, Girton College, 1869-1932, op. cit. (2), p. 176, and Newnham College Register, Staff, 1891. See also H. Wilson, 'Miss Freund', and M. D. Ball, 'Newnham Scientists', in A Newnham Anthology (ed. Ann Phillips', Cambridge, 1971, pp. 71-2 and 76-8, respectively. I thank Miss Ann Phillips for the information from the Newnham College Register.

43 Ida Freund, 'Der Einfluss der Temperatur auf die Volumenänderung bei der Neutralisation für verschiedene Salze bei verscheidenen Konzentrationen', Zeitschrift für physikalische Chemie, (1909), 66, pp. 555-613. 
Thomas retired, and the building can still be seen, though it is now used for other purposes'. ${ }^{44}$ Thomas published original work in stereochemistry, co-authoring several papers on the optical activity of nitrogen compounds with $\mathrm{H}$. O. Jones, the founder of the Cambridge School of Stereochemistry. ${ }^{45}$ This work related to questions concerning the planarity or non-planarity of the valencies of nitrogen, a subject receiving considerable attention at the time.

\section{THE LONDON COLLEGES}

Up to 1905 , more published research by women in the chemical sciences came from Cambridge than from any other single institution. However, taken together, the London colleges were the source of about 42 per cent of women's research during this period, with University College and the Royal College of Science being the most prominent. More than 75 per cent of the London women worked in one of the traditional areas of chemistry rather than in the new field of biochemistry, and from the beginning there was a noticeably greater trend toward collaborative work in London than in Cambridge, where about 70 per cent of women's papers in the period were published without a male co-author. (This compares with about 30 per cent of single-author papers by women at the London colleges ${ }^{46}$.) Thus, compared with Cambridge, the environment offered by the London colleges favoured the work of women as assistants and provided considerably less scope for their independent research. Nevertheless, throughout the twenty-five years from 1880 to 1905 some remarkably productive women chemists worked in the London institutions. Among the earliest, two in particular stand out: Emily Aston and Frances Micklethwait.

Emily Alicia Aston, born in $1866,{ }^{47}$ studied at Queen's College and Bedford College from 1883 to 1885 , and her first research was done in collaboration with P. S. U. Pickering at Bedford College. She was associated with University College from 1885 to 1899 , receiving her B.Sc. (honours in chemistry and geology) in 1889. In the late 1890s she spent some time at the University of Geneva and the Sorbonne. Her publications, in British and French journals, covered a wide range of topics, from mineral analyses and atomic weight determinations to organic structure studies. The most noteworthy are perhaps the series of papers on molecular surface energy, co-authored with Sir William Ramsay in the mid 1890s, and her work on optical rotation carried out with Paul Dutoit and Philippe Guye in the late 1890s. Aston is distinguished by being the first of the British women research chemists to produce a steady output of solid research (twelve papers) over a fairly extended period.

Frances Mary Gore Micklethwait ${ }^{48}(1868-1950)$ was among the most productive of the women researchers in the chemical sciences in any country in the period up to $1910 .^{49}$ Born

44 Needham, op. cit. (37), p. 158.

45 Berry and Moelwyn-Hughes, op. cit. (19), pp. 362-3.

46 Numbers of papers published by individual women are indicated in Appendix 1.

47 I thank Miss Carol R. Bowen, Records Office, University College, London, for information about Aston.

48 F. H. Burstall, 'Frances Mary Gore Micklethwait (1868-1950)', Journal of the Chemical Society, (1952), pt 3, pp. 2946-7. See also Who was Who (1941-50), London, 1952, iv, p. 791.

49 Probably the five most productive women in research in the chemical sciences in this period were Marie Curie, the Russian biochemist Nadezda Sieber-Schumov, Frances Micklethwait, the American public health chemist Ellen Swallow Richards, and the Swedish chemist Astrid Cleve von Euler; my unpublished data. 
in Monmouthshire, she was educated privately and then at Swanley Horticultural College, Kent. In 1898, at age thirty, she became a student at the Royal College of Science, and she was awarded the Associateship of the College in 1901. She stayed on over the next thirteen years and carried out varied series of researches in organic chemistry in collaboration with M. O. Foster, G. T. Morgan and J. C. Cain. Her work with Morgan on the diazo-reacrion applied to aromatic diamines was of special interest, and the formation and structure of the cyclic diazoimides was the subject of a number of papers in the Chemical Society journals. She and Morgan also investigated series of organo-arsenic and organo-antimony compounds. Throughout part of this work she was supported by a Beit Memorial Research Fellowship. She carried out war work for the Ministry of Munitions from 1914 to 1918 and for those services received the MBE in 1919. Soon afterwards, following a year at the Boots Research Laboratories in Nottingham, she returned to Swanley Horticultural College, where she was Principal from 1920 to 1921.

Martha Annie Whiteley (1866-1956), ${ }^{50}$ D.Sc. (London), was another notable chemist of the period. She was educated at Kensington High School, at Royal Holloway College (1887-91), and then at the Royal College of Science (1898-02). From 1898 to 1900 she taught science at Wimbledon High School, and then was a lecturer at St Gabriel's Training College for two years before joining the staff of the Royal College of Science in 1904 as an assistant in the Chemistry Department. She became a demonstrator in 1907, lecturer in 1913 at age forty-seven, and she was assistant professor from 1920 to 1934. Much of her original work, including notable investigations on tautomerism in oximes and syntheses in the barbiturate series, was carried out at the Royal College of Science between 1900 and 1909. In the 1920s she extended her early investigations to studies on oximes and amides of substituted malonic acids. Five substantial papers, co-authored by various collaborators including Edith Usherwood and Dorothy Yapp, appeared in the Chemical Society journals between 1921 and 1927. Her manual on organic analysis, written in collaboration with J. F. Thorpe, appeared in 1925. She was probably best known, however, as the editor of the fourth enlarged edition of the classic eleven-volume work, Thorpe's Dictionary of Applied Chemistry, to which she also contributed numerous articles.

Several more of this first generation of women chemists to come through the London colleges carried out notable research. For the most part, like Aston and Micklethwait, they are now forgotten, much of their work absorbed into the accomplishments of male collaborators, and their names omitted from the science histories of the period. Three of the especially productive people were Ida Frances Homfray, Effie Gwendoline Marsden and Nora Renouf. Ida Homfray, though she collaborated with P. A. Guye at the University of Geneva on surface tension studies and molar refractivity around 1904, worked mainly in Ramsay's laboratory at University College. Two substantial publications on surface properties which appeared between 1905 and 1910 were published under her name only, though she acknowledged Ramsay's advice. She held a London D.Sc. Effie Marsden also worked at University College, collaborating with E.C.C. Baly on studies relating absorption spectra to chemical constitution. Six papers co-authored by her appeared in the Chemical Society's Transactions between 1906 and 1910, including important basic studies on the problem of keto-enol tautomerism and the valency pattern of nitrogen. Also in

50 See Who was Who !1951-60), London, 1961, v, p. 1162. 
Baly's spectroscopy group were Katherine Alice Burke and Maud Gazdar. Burke also collaborated with Ramsay in his work on the radioactive elements. Nora Renouf's investigations, carried out with A. W. Crossley in the Research Laboratories of the Pharmaceutical Society between 1904 and 1914, are particularly elegant. Their fine synthetic and degradative work on compounds in the aromatic series, including the dihydrobenzenes, cleared up several questions from the earlier literature on chemical constitution. Renouf held a Salter's Research Fellowship for several years.

Of the early Royal College of Science women two, Dorothy Haynes and Hilda Mary Judd, who had begun their research careers in traditional areas of chemistry around 1905, later moved into biochemistry. Both became involved in investigations of the chemical changes taking place during the cold storage of fruits and related studies, work they carried out in the Department of Plant Physiology and Pathology of Imperial College, for the Food Investigation Board of the Department of Scientific and Industrial Research. ${ }^{51}$

Of all the London-trained women researchers in the chemical sciences who began their careers in the late Victorian era, perhaps the one who gained the most distinctions throughout her long professional life was Harriette Chick (1875-1977). ${ }^{52}$ The fact that she worked in biological chemistry can hardly be a coincidence. She went to Notting Hill High School and then studied science at University College, London. On graduating she received an 1851 Exhibition Scholarship which allowed her to work at the Hygienic Institutes of Vienna and Munich under Max Gruber, one of the pioneers in bacteriology, and then at the new Thompson-Yates Laboratories at Liverpool with Rupert Boyce. Her large-scale investigation of ground-water pollution was carried out at Boyce's suggestion. She received her D.Sc. in 1904, following her study of the effect of green algae in polluted water. In 1905, with a Jenner Memorial Research Studentship, she joined the Lister Institute, the first woman to do so. She remained there until her retirement in 1946, when she became an Honorary Member of the staff. Her early work at the Institute in collaboration with C. J. Martin concerned the mechanism of the process of disinfection. It led directly to the classic study by Chick and Martin which elucidated the process of coagulation of proteins by heat, and demonstrated that this was an orderly reaction governed by established chemical laws. ${ }^{53}$ The killing of bacteria by heat or disinfection was thereby removed 'from the realms of mysterious vital forces to that of a physico-chemical reaction. The way was thus paved for the development by which proteins came to be regarded as giant molecules which, with suitable techniques, could be studied in the laboratory as profitably as simple salts'. ${ }^{54}$ From 1914 onwards, largely as the result of her war-related work on food supplements to prevent deficiency diseases in troops, she concentrated on nutrition research, carrying out major studies on B vitamins. The work of the team she led in Vienna

51 Information about Haynes, Judd, Homfray, Marsden and Renouf was collected from their technical papers.

52 See A. M. Copping, 'Dame Harriette Chick', British Journal of Nutrition, (1978), 39, pp. 3-4; 'Dame Harriette Chick, D.B.E., D.Sc.', obituary in the British Medical Journal, (1977), pt 2, p. 270; Who was Who (1971-80), London, 1981 vii, p. 145; Chick, Hume and Macfarlane, op. cit. (28), pp. 87-92, 124, 147-160.

53 Charles James Martin and Harriette Chick, 'The heat coagulation of proteins', Journal of Physiology, (1910), 40, pp. 404-30. See also Edsall, op. cit. (25), p. 70.

54 Chick, Hume and Macfarlane, op. cit. (28), p. 92. 
from 1919 to 1922 elucidated the nutritional nature of rickets. ${ }^{55}$ On her return to the Lister Institure she resumed her research on the proteins and the vitamin B complex. She was Secretary of the Accessory Food Factors Committee of the Medical Research Council from 1925 to 1945, and of the League of Nations Health Section Committee on the Physiological Bases of Nutrition (1934-37). One of the founding members of the Nutrition Society, she served as irs President from 1926 to 1959 . Her work in nutrition research was recognized by the award of the CBE in 1932 and the DBE in 1949.

\section{OTHER COLLEGES AND UNIVERSITIES}

At institutions other than Cambridge and the metropolitan colleges, the marked increase in women's research activity came after $1905 .{ }^{56}$ However, even before the turn of the century there were a few women doing chemical research at some of the less prominent institutions (see Appendix 1). During the 1890s Marion Isabel Newbigin published several biochemical papers on plant and animal pigments from the laboratories of the Royal College of Physicians in Edinburgh, and Katherine Isabella Williams and Emily C. Fortey were working at University College, Bristol.

Williams, who became a student at Bristol in 1877 at age twenty-nine, passed the Cambridge Higher Local Examinations (1881-84) but did not proceed directly to any degree. Bristol awarded her a B.Sc. by research in 1910. She collaborated with Ramsay in the 1880s in studies of properties of the atmospheric gases, but then chose to move into the field of food analysis on her own and continued to publish in this area over a period of fourteen years. Her analytical work was 'much appreciated in America, where researches of this nature are systematically carried out'. ${ }^{57}$ She published two substantial papers in the Journal of the American Chemical Society in 1904 and 1907.

Emily Fortey's work is of special interest. She was a student at Bristol from 1892 to 1893 and from 1902 to 1903, and received a London B.Sc. in 1896 with honours in chemistry and experimental physics. She held a Bristol Chemical Scholarship in 1895-96, and was awarded an 1851 Exhibition Science Research Scholarship in 1896 when she was also awarded an Associateship of University College, Bristol. After some early work in photochemistry, published in 1896, she began a five-year collaboration with Sydney Young, co-authoring much of the work that formed the basis of Young's important treatise, Fractional Distillation (1903). Her own experience in the area was extensive: one of her first major papers described her laborious and painstaking work carried out at Owens College, Manchester, on the fractionation of crude petroleum samples from American and

55 The acute food shortages in Europe and especially Austria at the time, and the subsequent widespread appearance of deficiency diseases, provided a unique opportunity for rigorous testing of the hypotheses worked out at the Institute during the war years.

56 The changing pattern of the place of origin of women's research publications for the period 1905-10 is summarized in Appendix 2. The numbers have been extended back to 1900 to bring out in particular the steady contribution from Cambridge throughout the whole decade, and the noticeable increase in contributions generally, starting around 1905 , from the other three groups of institutions.

57 Record of the Council minutes, 1898-99, University College, Bristol. I thank Mr G. E. Maby, Archivist, University of Bristol, for information about Katherine Williams and Emily Fortey. 
Galician deposits. ${ }^{58}$ This work, in conjunction with that of the eminent Russian chemist V. V. Markownikoff, ${ }^{59}$ successfully demonstrated that the cyclohexane fractions from American, Galician and Caucasian deposits were identical, and identical to the synthetic product. Between 1899 and 1903 Fortey and Young published eight joint papers reporting their extensive and elegant studies on the theory of fractional distillation, work which quickly led to practical applications. ${ }^{60}$ Fortey's eight-year research career from 1896 to 1903 was remarkably productive, with fourteen substantial papers and several shorter communications. She herself, however, has joined the ranks of the 'invisible' women chemists. ${ }^{61}$

By the first decade of the twentieth century some notable research by women chemists was being done at Manchester, St Andrews and Oxford. Alice Emily Smith, an 1851 Exhibition Scholar of University College, Bangor, and later demonstrator in chemistry there, worked with both W. H. Perkins, Jr and K. J. P. Orton at Owens College, Manchester. Her joint research with Perkins in structure determinations and new synthetic routes in organic chemistry resulted in four substantial papers between 1902 and 1904, and her collaboration with Orton on reaction mechanism studies (1905-08) was equally productive. Eva Hibbert, an analytical chemist, collaborated with Edmund Knecht at the Municipal School of Technology, Manchester. Her publications on analytical methods started in 1903 and continued into the 1920s. At the University of St Andrews, Agnes Marion Moody's joint work with J. C. Irvine on sugar chemistry began in 1905. Moody was probably the earliest of the notable women research chemists at a Scottish University. She held first a Berry Scholarship and then Carnegie Scholarships over several years. At Oxford University Florence Isaac's studies with Sir Henry Miers on mixed crystals and the theory of crystallization resulted in seven substantial publications between 1906 and 1910 . Isaac held a Mary Somerville Research Fellowship of Oxford (1906-09), but her undergraduate education was at Girton College, Cambridge. ${ }^{62}$

\section{THE PROFESSIONAL SITUATION OF EARLY WOMEN RESEARCH CHEMISTS, WITH COMPARISONS WITH CONTEMPORARY WOMEN IN OTHER SCIENTIFIC DISCIPLINES}

A remarkable number of the first generation of women with university-level training in the chemical sciences participated in original work. However, it is fairly clear from the careers

58 Emily C. Fortey, B.Sc., 'Hexamethylene from American and Galician petroleum', Journal of the Chemical Society, Transactions, (1898), 73, pp. 932-49.

59 V. V. Markownikoff ['Recherches sur les composés cycliques de la série de l'hexamethylene'], Journal of the Russian Physico-Chemical Society, (1898), 30, pp. 59-90, 151-95; Bulletin de la Société Chimique de Paris (1898), 20, pp. 851-6; [Liebig's] Annalen der Chemie, (1898), 301, pp. 154-202; 302, pp. 1-42.

60 The technique used in the final stages of the commercial production of water-free 'absolute' alcohol was based on one of Fortey and Young's 1902 observations on the behaviour of mixed liquids. See E. E. Turner and Margaret Harris, Organic Chemistry, London, 1952, pp. 60-1.

61 Emily Fortey is referred to, though only by surname ('Young and Fortey, 1902') in Turner and Harris, ibid., p. 60 .

62 Information on Smith, Hibbert, Moody and Isaac was collected from their technical papers. Isaac is also mentioned in Byrne and Mansfield, op. cit. (2), p. 96. 
just described that those who were most successful as independent researchers were not in established areas of chemistry but rather in the emerging field of biochemistry. Except for Harriette Chick who trained in London, the majority of the early women biochemists were Cambridge-educated. The most notable were Greenwood, Tebb and Smedley, and, somewhat later, Wheldale and Stephenson. The nature of biochemical research, making team-work natural and sometimes essential, frequently leads to joint publications. However, it is evident from their papers (some joint and some single-author), the monographs several of them wrote, obituaries, and available accounts, ${ }^{63}$ that the outstanding women in early biochemical research were not assistants but partners. In some cases (for instance Chick at the Lister Institute) they were team leaders.

Of the early women research workers in traditional areas of chemistry the three most productive in the period before 1905 were Aston and Micklethwait at University College, London, and Fortey at University College, Bristol. None of these, or indeed any of the slightly later and notably productive women chemists such as Marsden, Renouf, Alice Emily Smith or Isaac, produced a substantial body of independent work. Most of their publications are joint with eminent male co-authors, and almost the only records of their research careers are those co-authored papers in the technical journals. They appear, therefore, in the role of assistants rather than partners. Micklethwait, the most outstanding in terms of number of co-authored publications, was described by her obituarist as being 'of a modest and retiring disposition', which 'was reflected in her preference for working in collaboration rather than striking out on lines of her own ${ }^{64}$ Their records of joint publications would seem to suggest that, generally speaking compared with the women biochemists, most of the women researchers in established areas of chemistry were of a similar 'modest and retiring disposition' - a curious coincidence. In Micklethwait's case the fact that she later overcame her diffidence sufficiently to accept the position of Principal at Swanley Horticultural College, if only for a brief post-war period, suggests that her years of collaborative work might have owed something to lack of reasonable opportunity for any alternative research career. It is also rather striking that several of the women chemists who later moved into biochemistry published single-author papers in the latter field even though their earlier work in traditional chemistry generally appeared as co-authored publications with men. The careers of Homer, Haynes and Judd followed this pattern.

Micklethwait, however, was at least accorded an obituary in which she was recognized by a contemporary as a 'fine chemist' ${ }^{65}$ Fortey and Aston, on the other hand, disappeared into obscurity, despite Aston's place as the first notable British woman research chemist, and Fortey's impressive collaborative work with Sydney Young. Martha Whiteley is an exception to the 'female assistant' pattern. Though she was not outstandingly productive her research contributions were substantial; indeed, of the early British women she was probably one of the most successful in establishing herself as an independent investigator in a traditional area of chemistry and remaining active in writing and research throughout much of her long career. This acknowledged, it remains the case that her best-known work is editorial. Both Freund and Thomas, two other life-long professional academics in

63 See for instance Chick, Hume and Macfarlane, op. cit. (28), and Kohler, op. cit. (20).

64 Burstall, op. cit. (48), p. 2947.

65 Ibid., p. 2947. 
traditional areas of chemistry, are remembered as teachers rather than as researchers: Thomas's original work was all collaborative, and Freund's most important publication was her classic textbook.

Thus, for the most part, British women of this period who were interested in doing research in the chemical sciences at anything beyond the assistant level generally found their opportunities in areas other than the established branches of the field. A similar pattern has been noted in the careers of American women chemists of the turn of the century. Of the group of ten women analytical chemists who received Ph.D. degrees from the University of Pennsylvania between 1894 and 1908, only one, Mary Engle Pennington, had a successful career in the established scientific community; most of Pennington's work was in applied bacteriological chemistry (food preservation) and from there she moved into refrigeration engineering, another new and developing field at the time. ${ }^{66}$

The difficulties encountered by women chemists in establishing themselves as independent workers and being recognized as such are emphasized further by comparisons with fields other than biochemistry. In geology, for instance, a discipline in which in Britain during the late nineteenth century there were less than half as many women active in research as in chemistry, ${ }^{67}$ several women made major independent contributions, which were recognized by the Geological Society by the award of notable honours (notwithstanding the fact that women were not accepted as Fellows of the Society until 1919). For instance, the mineralogist and petrologist Catherine Raisin, head of the Geology Department at Bedford College from 1890 to 1920, received the Lyell Fund in 1893; Mary Jane Donald, the invertebrate palaeontologist from Carlisle, the Murchison Fund in 1898; Gertrude Elles, the Cambridge palaeontologist, the Lyell Fund in 1900; Elles's colleague Ethel Wood the Wollaston Fund in 1906; and another Cambridge palaeontologist, Ethel Skeat, the Murchison Fund in 1908. In 1919, when she became a Fellow of the Geological Society, Elles was honoured with the Murchison Medal and Ethel Wood received the same award the following year. Maria Ogilvie Gordon, the Scottish field geologist, whose fortyyear career was devoted to the study of the stratigraphy and tectonics of the Austrian Tyrol, was awarded the Lyell Medal in 1932, though the University of Innsbruck and the Geological Survey of Austria had honoured her previously. ${ }^{68}$

Likewise in botany several of the first generation of women graduates went on to independent work, contributing basic theoretical ideas to the field and being duly recognized for these contributions. One of the outstanding early women was the

66 See Lisa Mae Robinson, 'The electrochemical school of Edgar Fahs Smith, 1873-1913', University of Pennsylvania, Ph.D. dissertation, 1986, pp. 231-3; university microfilm no. DET87-03261. Also Mary R. S. Creese and Thomas M. Creese, 'Mary Engle Pennington', in the forthcoming book Women in Physics and Chemistry (ed. L. Grinstein), Westport, Conn., 1991.

67 Unpublished data, derived from an analysis of the references to papers by women scientists listed in the Royal Society's Catalogue of Scientific papers, i-xix.

68 The careers of these early women geologists are outlined in obituaries in the technical journals. See Doris L. Reynolds, 'Dr Catherine Alice Raisin', Nature, (1945), 156, pp. 327-8; L. R. Cox in the Proceedings of the Geological Society, (1935), 91, pp. xcvii-xcviii (Donald); O.M.B.B. ibid. (1901), no. 1592, pp. 143-5 (Elles); G[ertrude] L[ilian] E[lles] in the Quarterly Journal of the Geological Society, (1946), 102, pp. xlvi-xlvii (Wood); H. W[oods] in the Proceedings of the Geologists' Association, (1940), 57, p. 114 (Skeat); Julius Pia, 'Maria Matilda Ogilvie Gordon', Mitteilungen der Geologischen Gesellschaft in Wien, (1939), 32, pp. 173-86. 
Cambridge plant geneticist and floral morphologist Edith Saunders, a colleague of Marion Greenwood. Saunders' prominent position in her field was reflected in her selection as President of Section K (Botany) of the British Association for the Advancement of Science (BAAS) in 1920, and she was President of the Genetical Society in 1936. Another Cambridge-educated botanist, Ethel Sargant, outstanding for her work in cytology and the anatomy of seedlings, was the first woman ever to preside over a Section of the BAAS, being elected President of Section K in 1913. Ethel Miles Thomas, a close associate of Sargant, went on to a long academic career, first at Bedford College, later as head of the Botanical Department at University College, Cardiff, and, by the 1920s, as lecturer in biology at University College, Leicester. She also held national and international office, as Vice-President of Section K of the BAAS in 1933 and as a member of the executive committee of the Imperial Botanical Conference in 1924. ${ }^{69}$

On the other hand, despite this apparent success, it is also the case that of these seven prominent women scientists only four held salaried positions; Raisin at Bedford College, Saunders at Newnham College, Elles also at Newnham until in 1926 at age fifty-four she received a University appointment at Cambridge, and Thomas at successively, Bedford College, University College, Cardiff, and University College, Leicester. Ogilvie Gordon, Donald and Sargant were independent research workers, living on family funds in a manner more typical of the 'amateur' male scientists of an earlier era, and not competing for salaried positions despite life-long commitments to first class scientific work. Despite professional recognition by their peers and notable honours, these scientists, the ablest of the women researchers in their fields, were on the very margins of the scientific community as far as consideration for such positions was concerned. Nevertheless, they and the women biochemists whose careers are outlined above did achieve success as independent researchers. Corresponding success and recognition by the established chemical community for women in traditional areas of chemistry is hard to find.

Although the laboratory requirements of plant physiologists like Saunders and Sargant, and petrologists and mineralogists like Raisin, were probably considerably less than those of chemists, even by 1910 the needs of biochemists and chemists would have been more comparable. Therefore, simply the possibility of more restricted access to the tools of the trade does not by itself adequately explain the relative lack of success of women as independent research chemists.

In the case of the biochemists, their field at the time was a developing discipline. The entry paths and entry qualifications of its practitioners were not well defined. F. G. Hopkins himself, the 'father' of the field, was 'a practical clinical chemist', who 'felt acutely his lack of collegiate polish and credentials'; he had trained by apprenticeship as an analytical chemist and his subsequent university education was in medicine. ${ }^{70}$ Until after the Second World War the number of academic positions for research biochemists in British universities was extremely limited, and most worked in institutions which had less

69 For information about Saunders, Sargant and Miles Thomas see respectively: H. Godwin, A. R. Clapham and M. R. Gilson, 'Edith Rebecca Saunders, F.L.S.', New Phytologist, (1946), 45, No. 1, pp. 1-3; D. H. S[cott], 'Miss Ethel Sargant, F.L.S.', Annals of Botany, (April, 1918), 32, no. 126, pp. i-v; 'Dr E. N. Miles Thomas', Nature, (1944), 154, pp. 481-82.

70 Kohler, op. cit. (20), p. 49. 
academic prestige, those doing practical, applied research - hospitals, sanitary commission laboratories and research institutions, ${ }^{71}$ of which the largest was the Lister Institute. This lack of prestige, due to the slowness of academic chemists to recognize the full power and potential of research in the field, ${ }^{72}$ offers one explanation for its relative openness to women. A second and more specific factor in the success of the women biochemists associated with Cambridge was the role played by Hopkins, whose career there began in 1898. At a time when there were practically no women research workers in any of the other university departments at Cambridge, Hopkins gave them places in his, despite the criticism which this brought him. Even in the 1920s and 1930s, when, as a Nobel laureate with a world-wide reputation he received hundreds of applications for places in his laboratory, nearly half of the posts in his Department went to women scientists. ${ }^{73}$ Furthermore, Hopkins' personal style was an important influence:

He was a great giver and receiver of moral support ... he was open to receive it from the most junior of his research workers, so that they did not feel he was encouraging them like some deus ex machina, but as one of themselves; in other words he fully understood and practised the great doctrine of leadership from within and not from above. ${ }^{74}$

This support and encouragement which Hopkins provided so well were of the greatest importance to women scientists struggling for professional opportunities in the face of general opposition. It is also evident that Hopkins suffered no disadvantage from his choice of many women co-workers, for his Department at Cambridge at this period by far surpassed all other biochemical institutions 'in its diversity of research specialties and its broad biological vision of biochemistry as a discipline '. ${ }^{75}$

A somewhat comparable situation arose in X-ray crystallography, a field which developed just after the First World War, and in which women have been relatively prominent from the beginning. The atmosphere of the field in its early days has been characterized as 'unaggressive low-key friendly' and 'uncompetitive'. It was the kind of society which tends 'to be good for women' ${ }^{76}$ Both W. H. Bragg and his son W. L. Bragg, the two founders of X-ray crystallography in Britain, welcomed women into their

71 Ibid., pp. 60-1, 65-71.

72 Ibid., pp. 62-5. Although the general patronizing attitude of academic chemists towards biochemistry lasted into the 1920s, recognition of the practical importance of the field gradually grew in the preceding decades. In 1902 the Royal Institute of Chemistry officially recognized 'biological chemistry' as a branch of the field with its own qualifying examination (Richard B. Pilcher, The Institute of Chemistry of Great Britain and lreland, History of the Institute: 1877-1914, London, 1914, pp. 150, 155), and in 1907 Raphael Meldola, in his presidential address to the Chemical Society, acknowledged the national importance of research coming from establishments such as the Lister Institute, which he placed among the most important centres of research activity in the country; Meldola, 'The position and prospects of chemical research in Great Britain', Journal of the Chemical Society, Transactions, (1907), 91, pp. 626-58, esp. pp. 635-6.

73 Richter (ed.), op. cit. (34), p. 7.

74 J. Needham, 'Sir F. G. Hopkins' personal influence and character', in Hopkins and Biochemistry (ed. J. Needham and E. Baldwin), Cambridge, 1949, pp. 114-15, quoted in Kohler, op. cit. (20), p. 88.

75 Kohler, op. cit. (20), p. 88.

76 The field was so described by Anne Sayre, author of Rosalind Franklin and DNA, New York, 1975, and wife of crystallographer David Sayre. She is quoted by Maureen M. Julian, 'Women in crystallography', in Women of Science. Righting the Record (ed. G. Kass-Simon and Patricia Farnes), Bloomington, Indiana, 1990, pp. 339-40. 
laboratories from the beginning, and the early success of one or two outstanding women was a key factor in ensuring their continuing presence in the field. These first-generation women crystallographers, and equally importantly, their male co-workers, in turn accepted and encouraged a second generation of women as students and colleagues.

In geology the continuation among men of the amateur and professional traditions side by side, and the acceptance of 'amateurs' as important contributors to geological research until well into the twentieth century, ${ }^{77}$ may perhaps have given the discipline a relatively more open outlook and helped to make the presence and work of women geologists more acceptable. In botany a similar tradition of accepting serious contributions from 'amateurs' had long existed. ${ }^{78}$ It is perhaps also significant that plant physiology, the area of interest of Sargant, Saunders and Thomas, which had been undergoing rapid development since the middle of the century, had, by the 1890s, close connections with biochemistry. ${ }^{79}$

Chemistry on the other hand, was both a well-established field and one in which access to adequate facilities for research was more subject to restriction. There was little role for the 'amateur'. Thus, there was no special factor or set of circumstances that aided the entry of the first women graduates into the profession and helped them establish careers as independent researchers. Good will and some assistance in finding opportunities for research was indeed provided by some of the leading male chemists, including Sir James Walker, Sir Martin Onslow Forster and E. C. C. Baly; Sir William Ramsay, who had several women protégés, is particularly noteworthy (see Appendix 1). But the field had no one who played a role equivalent to that of Hopkins or the Braggs in promoting with real effectiveness the acceptance of the early women as independent researchers. Despite the much greater number of established university departments and therefore of academic positions in chemistry compared to biochemistry, women had little success in making their way into anything beyond the lowest levels, and consequently their opportunities for independent research were severely limited. Martha Whiteley's promotion from lecturer to assistant professor at Imperial College in 1920, at the age of fifty-four, was exceptional, and her return to productive research at that date after a lapse of several years significant. As an assistant a woman chemist had no possibility of building up a substantial body of work which she could claim as her own. She simply helped someone else to carry out his projects. Thus, very few of the early British women chemists in traditional branches of the subject have a place in the story of the conceptual development of their field. The biochemists Smedley, Wheldale and Stephenson, the geologists Elles and Ogilvie Gordon, the botanist Saunders all became authorities in their chosen areas of research and wrote important and well-received monographs; but Fortey's work went into Young's monograph and Marsden's into Baly's.

The story of the women's forty-year struggle for admission to Fellowship in the Chemical Society offers some illustration of the long-standing resistance they faced in their

77 See for example Jean G. O'Connor and A. J. Meadows, 'Specialization and professionalization in British geology', Social Studies of Science, (1976), 6, pp. 77-89, and Roy Porter, 'Gentlemen and geology : the emergence of a scientific career, 1600-1920', The Historical Journal, (1978), 21, 4, pp. 809-36.

78 See David Elliston Allen, The Naturalist in Britain. A Social History, London, 1976.

79 A. G. Morton, History of Botanical Science, London, 1981, esp. pp. 425-8. 
efforts to enter fully into the research community. A proposal for their admission had been put to the Sociery's Council as early as 1880 and the question was taken up again in 1888 and 1892, but on all three occasions the proposal was rejected. ${ }^{80}$ In 1904 , in response to a memorial presented by nineteen women chemists, all of them lecturers at women's colleges, demonstrators, or actively engaged in research, and all having full qualifications for membership, the Council again took up the question. They proposed an alteration of the Society's bye-laws extending the privileges of Associateship to women. The Fellows rejected this proposal. In 1908 the question was raised yet again, Ida Smedley and Martha Whiteley being the chief organizers of the effort. By then the number of qualified women wanting to join had risen to twenty-eight. In support of a memorial submitted to the Council stating their request for admission, the women chemists collected the signatures of ' 312 Fellows (including 10 past presidents, 12 vice-presidents and 27 members of Council, past and present) among whom were 33 Fellows of the Royal Society, and the heads of the chemical departments of nearly all the most important universities and colleges in the kingdom'. It was, commented the editor of Nature, 'the most influentially signed memorial that body has ever received '. ${ }^{81}$ The membership was then invited to vore on the matter, and a letter in which the Council set forth both sides of the question was sent out with the ballor papers. The arguments put forward against the admission of women included doubts about the advisability of encouraging women to be professional chemists because of the 'arduous nature of chemical work', and uncertainty about women having shown any 'marked aptitude for chemical pursuits' despite their very good publication record in the Society's journals. Those against considered it generally 'inexpedient publicly to encourage women to adopt chemistry as a professional pursuit, since such a course would tempt them into a career in which they may ultimately not find employment in view of the already overcrowded state of the profession ${ }^{2}{ }^{82}$ The result of the ballot was 1094 in favour, 642 against and 22 neutral; but the Council, on the basis of dubious legal arguments, decided not to go along with the vote. The women were granted instead 'Lady Subscriber' status, with no voting rights, which few of them were willing to accept. Their defeat by a powerful minority group (the Council), and the subsequent acceptance by the Society of the minority decision, is remarkable. Clearly there was not a sufficiently strong feeling within the Society in support of the women to risk disrupting the harmony by questioning the Council's decision. ${ }^{83}$ It required another twelve years to

80 At least three other national chemical societies had women members well before the turn of the century. Anna Fedorovna Volkova, a student of Mendeleev, joined the Russian Chemical Society in 1870 (see Iu. S. Musabekov, Iulia Vsevolodouna Lermontova, 1846-1919, Moscow, 1967, p. 8), and there were several women in the German Chemical Society by the 1880s, and in the American Chemical Society by the 1890s (see membership lists in the Berichte der deutsche chemische Gesellschaft and the Journal of the American Chemical Society, respectively).

81 'Women and the Fellowship of the Chemical Society', Nature, (9 July 1908), 78, pp. 226-8, esp. p. 226.

82 Ibid., p. 227.

83 The fraction of the fellowship actively in support of membership for women was not as high as the voting figures might suggest. Out of a total membership of 2896,1758 (60.7 per cent) returned ballots. Thus, of the Society as a whole, 37.8 per cent were actively in favour of the admission of women, 22.1 per cent were actively against, and the rest were neutral or did not consider the matter of sufficient interest to vote. Membership data and voting figures are from the report of the Annual General Meeting, 25 March 1909, Journal of the Chemical Society, Transactions, (1909), 95, pp. 611-23, esp. pp. 612, 614-16. 
muster sufficient support to overcome the opposition: women were not admitted to the Fellowship until $1920 .^{84}$ The idea that chemistry was a profession established for men died hard.

\section{THE POSITION OF CAMBRIDGE IN SCIENCE EDUCATION FOR WOMEN}

Clearly Cambridge occupied a special position in the education of the first generation of British women scientists, producing many of the most distinguished. The pre-eminence of these early Cambridge women was not confined to those in any one scientific field nor even to those who came through the NST curriculum, there being also several outstanding early women who took the Mathematical Tripos. ${ }^{85}$

One of the important factors which put Cambridge in this special position was the close and early established connection between Girton and Newnham Colleges and several of the leading English schools for girls from the middle classes. The efforts by Girton's founder, Emily Davies, to get the older universities to open their Local (entrance) Examinations to girls had succeeded first at Cambridge, which admitted girls to its 'Locals' in $1865 .{ }^{86}$ As well as constituting an important step in establishing standards in girls' secondary education, this move by Cambridge led Emily Davies to work towards linking her proposed college for women with that university; Hitchin College (Girton's forerunner) opened in 1869. Oxford, on the other hand, had rejected Miss Davies' request, preferring 'to let Cambridge take the risk of such a novel experiment' ${ }^{87}$ The Oxford Local Examinations were not opened to girls until 1879, the year in which the two Oxford women's colleges, Lady Margaret Hall and Somerville College, first accepted students, and one year after University College, London, opened to women. ${ }^{88}$

Starting about 1870, education for girls in England went through a period of vigorously

84 Martha Whireley outlined the stages in the history of the opening of Fellowship in the Chemical Society to women in her obituary of Ida Smedley MacLean, op. cit. (28), pp. 66-7. See also the Journal of the Chemical Society, Transactions, (1905), 87, pp. 538-9; Proceedings, (1905), 21, pp. 41-59; Transactions, (1909), 95, p. 614.

85 Charlotte Angas Scott, a Girton student, placed equal to the eighth Wrangler in the Mathematical Tripos (MT) of 1880. She received a London D.Sc. in 1885, and spent her working life at Bryn Mawr College, Pennsylvania, publishing a considerable amount of original work and becoming Vice-President of the American Mathematical Society in 1906. Isabel Madison, a mathematics student at Cambridge from 1889 to 1892, also had a successful career at Bryn Mawr. Her friend Grace Chisholm (Girton 1889-92) was a Wrangler in Part I of the MT in 1892, received a Ph.D. from the University of Görtingen in 1896 and later published notable work in the modern theory of real functions. Phillipa Fawcett, a student of J. J. Thompson, placed above the Senior Wrangler in the MT of 1890. After a short time as a lecturer at Newnham she went on to a distinguished career in educational administration, first in South Africa and then in London. Mary Ellen Rickett, a student at Newnham from 1881 to 1886 , was one of the few women who took both the Classical Tripos and the MT. In the latter she placed equal to the twenty-fourth Wrangler. She was a lecturer in mathematics at Newnham and Vice-president of Old Hall, Newnham, from 1889 to 1910 . Information about these five women came from the following sources: Ogilvie, op. cit. (1), pp. 158-9 (Scott); obituary in the New York Times, 24 October 1950, p. 29 (Madison); M. L. Cartwright, 'Grace Chisholm Young ', Journal of the London Mathematical Society, (1944), 19, pp. 185-92; Who was Who (1941-50), London, 1952, iv, p. 376 (Fawcett); Tuke, op. cit. (2), p. 311 (Rickett).

86 Stephen, Emily Davies and Girton College, op. cit. (2), p. 128; McWilliams-Tullberg, op. cit. (2), p. 34.

87 Ibid., pp. 35, 108.

88 Ibid., p. 108. See also Tuke, op. cit. (2), p. 132. 
conducted reorganization following the 1867-68 Report of the Schools Inquiry Commission. Largely due to Emily Davies' efforts, girls' schools had been included in the Report's terms of reference, and the great need for reform was made plain. ${ }^{89}$ By 1894 there were over 200 new or reorganized endowed or proprietary schools for girls, the majority dating from the period after $1870{ }^{90}$ Consequently the presence at Cambridge of Emily Davies, one of the most prominent figures in the whole movement for the reform of female education, and the few years of head start in university-level education which Girton and Newnham had in the early 1870s, put Cambridge in a key position: with still only a small number of women asking for university-level training, ${ }^{91}$ and a substantial fraction of them becoming the headmistresses and assistant mistresses in the new girls' schools, the first of the Cambridge-trained women from the early 1870 s established important connections between their colleges and some of the best of the new girls' schools. These were also the schools which, in line with recommendations made in the Schools Enquiry Commission Report, ${ }^{92}$ began to emphasize science teaching in their curricula.

The connection between Newnham College and King Edward's School, Birmingham, which opened in 1883 and was the girls' school with the best reputation for science teaching in England, has already been noted. Edith Creak, the first headmistress and a pioneer in the teaching of science to girls, was one of the original five Newnham students. She took both the mathematical and the classical Triposes in 1875, at age twenty, and shortly thereafter a London BA with first class honours. 'Everything about her was strong, and strongest of all was her loyal devotion to Newnham. ${ }^{, 93} \mathrm{Her}$ school sent many distinguished science students to Newnham, and the science staff for many years was made up of Newnham women.

Girton College had strong ties in its early years with the North London Collegiate School, which, opened in Camden Town in 1850 by Frances Mary Buss, was the girls' school which became the model for Day Schools in England. Science was included in its curriculum from the beginning. ${ }^{94}$ Likewise the teaching staff at the Manchester High School for Girls, opened in 1874, included Cambridge women ${ }^{95}$ Amy Bulley had been one of the first group of Newnham students, and Sarah Woodhead, who took the Mathematical Tripos in $1872,{ }^{96}$ one of the Hitchin College pioneers.

Thus, two points in particular emerge: first, Cambridge occupied a central position in the network of newly founded institutions which were promoting the education of women

89 McWilliams-Tullberg, op. cit. (2), pp. 36-49; Joyce Senders Pedersen, 'Schoolmistresses and headmistresses: elites and education in nineteenth century England', The Journal of British Studies, (1978), 15, no. 1, pp. 135-62; J. L. Richardson, 'The great revolution; women's education in Victorian times', History Today, (1974), 24 pp. 420-7; Stephen, Emily Davies and Girton College, op. cit. (2), pp. 128-47.

90 Pedersen, op. cit. (89), p. 148.

91 Tuke, op. cit. (2), p. 132.

92 D. S. L. Cardwell, The Organization of Science in England, London, 1972, pp. 114-15; Robert Budd and Gerrylyn K. Roberts, Science versus Practice, Chemistry in Victorian Britain, Manchester, 1984, pp. 120, 130.

93 Hamilton, op. cit. (2), pp. 96, 110, 114, the quote being from p. 114.

94 The North London Collegiate School, 1850-1950. A Hundred Years of Girls' Education (ed. R. M. Scrimgeour), London, 1950, pp. 30-3.

95 Tylecote, op. cit. (2), p. 26.

96 Stephen, Emily Davies and Girton College, op. cit. (2), p. 276. 
in the sciences, ${ }^{97}$ and the early-established connections between Girton and Newnham Colleges and the leading girls' schools brought a steady supply of exceptionally able and well-qualified women students into the science honours (Tripos) courses. Secondly, and of particular importance to women in the chemical sciences, was the encouragement and the opportunities for research in biochemistry/physiology available to the NST students. This was backed by outstanding grounding in chemistry provided by Freund and Thomas in the Newnham and Girton College chemical laboratories.

Appendix 1. List of British women who authored at least one publication in the chemical sciences before 1906, with an indication of the kind of work in which they were engaged

Notes

(a) For completeness, the names of those discussed in the text, with location and publication count to 1905 , are repeated here. These are marked with an asterisk (*). Those referred to in the text more briefly are marked with a dagger $(t)$.

(b) For the others, college associated with and/or the laboratory where the work was done are listed where known, the information coming typically from the person's technical papers.

(c) In square brackets are given: (i) the number of publications, excluding short notes (except in a few cases where these are the only records of the work), up to 1905 ; (2) area of activity during this period; (3) co-author, if any; (4) time-span for appearance of papers.

(d) Some entries include brief statements about later careers.

\section{Cambridge}

ALcock, Rachel. Bathurst student, Newnham. [2; bacteriological chemistry; 1892-99].

Dawson, Maria, B.Sc., London. 1851 Exhibition Science Research Scholar; Botanical

laboratory. [3; biochemical, nitrogen fixation; 1898-01].

"Durham, Florence Margaret. Girton. [1; biochemical, animal pigment studies; 1904].

Earp, (Miss) A. G. [1; physical constants; 1893].

Eves, Florence. Newnham. [2; sugar/starch metabolism, including 1 with J. N. Langley; 1883-84].

FiELD, Eleanor. Demonstrator in chemistry, Newnham. [2; inorganic, constitution of salts; 1892-93]. Was later staff lecturer in chemistry, Royal Holloway College.

"Freund, Ida. Girton and Newnham. [1; general, textbook; 1904].

Gostling, Mildred, B.Sc., London (later Mrs W. H. Mills). Bathurst Student, Newnham.

[5; organic, carbohydrates, including 4 with H. J. H. Fenton; 1898-03].

"Greenwood, Marion, Girton and Newnham. [5; physiological chemistry; 1884-95].

97 In contrast, Oxford at this early period, though it educated its share of women who went on to distinguished careers, including many in the reaching profession, produced relatively few women who contribured to original work in the chemical sciences (see Appendix 1). The most eminent of the Oxford women were, typically, historians, linguists, writers, and administrators; see, for instance, the accounts of Brittain, Byrne and Mansfield, and Bailey, op. cit. (2), in which hardly any women scientists are mentioned. 
HartLe, Hilda J., B.Sc. Newnham and University of Birmingham. [1; optical activity studies with P. F. Frankland and L. Heathcote; 1903]. Went to Newnham from King Edward's School, Birmingham; Gilchrist Fellow; NST 1901 (Class I, chemistry, Part II); later lecturer in chemistry, Homerton Training College, Cambridge, and then Principal, Brighton Training College.

Matthaei, Gabrielle L. C., BA (later Mrs Howard). Newnham. [2; biochemical, plant metabolism, including 1 with F. F. Blackman; 1903-05].

SEDGwICK, Annie Purcell (later Lady Walker). Laboratory of Gonville and Caius College; University College, London; University College, Dundee. [3; organic synthesis, 1 with S. Ruhemann, 1 with J. N. Collie and 1 with J. Walker; 1895-05].

"SidG WICK, Eleanor Mildred Balfour. Newnham. [2; electrochemistry, with Lord Rayleigh; 1883-84].

Stater, Jessie Mabel W., B.Sc., London. Bathurst Student, Newnham. [1; physical, radio activity; 1905].

"Smedley, Ida, D.Sc. Newnham. [4; physical-organic; 1900-05].

*TEBB, Mary Christine. Girton and King's College, London. [7; biochemical, including 1 with E. L. Shore; 1892-05].

†Tномаs, Mary Beatrice. Newnham and Girton. [1; spectroscopic studies with H. O. Jones; 1905].

†W ILLCOCK, Edith Gertrude (later Mrs J. S. Gardiner). Newnham. [3; physical and biochemical, including 1 with W. B. Hardy; 1903-04].

\section{London}

(UC = University College; RCS $=$ Royal College of Science, $\mathrm{BC}=$ Bedford College $).$

*Aston, Emily Alicia, B.Sc. BC, UC, University of Geneva and the Sorbonne. [12; 10 are joint papers, co-author varies; $1885-02]$.

BOoLE, Lucy Everest, FIC. Lecturer in chemistry, London School of Medicine for Women; Research Laboratory, Pharmaceutical Society. [2; analytical, with W. R. Dunstan; 1889-95]. Was the first women co-author to have a paper read before the London Pharmaceutical Society. ${ }^{98}$

†Burke, Katherine Alice, UC and Royal College of Science, Dublin. [1; reaction rate studies, with F. G. Donnan; 1904].

"CHICK, Harrietre, B.Sc, D.Sc. UC and Thompson-Yates Laboratory, Liverpool. [2; 1 bacteriological, and 1 organic with Sir Wm Ramsay and F. Collingridge; 1900-02].

Dougal, Margaret Douie. RCS. Indexer of the publications of the Chemical Society for fifteen years, until 1909. [6; inorganic/analytical; 1893-96]. Was also responsible for the preparation of the collected decennial indices of the publications of the Chemical Society. ${ }^{99}$

98 Wyndham Rowland Dunstan and Lucy Everest Boole, 'Chemical observations on tartar emetic', Pharmaceutical Journal and Transactions, (1889), III, 19, pp. 385-7, and discussion pp. 397-9.

99 A Collective Index of the Transactions, Proceedings and Abstracts of the Chemical Society, for the period 1873-1912, 4 vols., London [n.d.]. Vols. i-iii were compiled by Mrs Dougal. The importance to the Society of this major indexing project and Mrs Dougal's many-year commitment to the work were acknowledged by Sir James Dewar in his Presidential Address to the Society, 1899; Journal of the Chemical Society, Transactions, (1899), 75, p. 1168. 
Evans, Clare de Brereton, B.Sc., D.Sc. Central Technical College. [4; organic, studies on aromatic amines; 1895-97]. Was later lecturer in chemistry, London School of Medicine for Women; published 2 more papers in 1908 on mineral analyses done at UC.

EWBANK, Elinor Katherine. UC. [2; ultra-violet spectra of aromatic compounds, with E.C.C. Baly; 1905]. Later collaborated with N. V. Sidgwick at Oxford, and published several joint papers in the 1920s.

Farrer (Miss) E. M. BC. [1; inorganic, with P. S. U. Pickering; 1886].

"Fulhame, Elizabeth. [1; inorganic, monograph; 1794].

HalCRow, Lucy. RCS. [1; water analysis/pollution studies, with E. Frankland; 1880]. Was probably the first woman co-author to have a publication in the Transactions of the Chemical Society. ${ }^{100}$

Hall, Lucy. UC. [2; organic synthesis, 1 with J. N. Collie and 1 with F. S. Kipping; 1898-99].

†Haynes, Dorothy. RCS. [1; physical-organic, with J. C. Philip; 1905].

†HomfraY, Ida Frances. B.Sc., D.Sc. UC and University of Geneva. [4; mainly surface tension and molecular refraction studies, including 1 with P. A. Guye, and 1, analytical, with Sir Wm Ramsay; 1901-05].

HOOPER, Elsie S. Research Laboratory, Pharmaceutical Society. [2; analytical, including 1 with H. G. Greenish; 1904-05].

Huggins, (Lady) Margaret. Tulsa Hill Observatory. [4; physical, joint work with Sir Wm Huggins on spectral determinations; 1903-05]. Joint work on chemical spectra continued through 1906.

†JudD, Hilda, Mary, B.Sc. RCS. [1; organic synthesis and structural studies, with M. O. Forster; 1905].

JuDson, Winifred, B.Sc. UC. [1; reaction rate studies with J. W. Walker; 1898].

LAKE, Hilda. RCS. [1; plant biochemistry, with E. Drabble; 1905].

LANE-Claypon, Janet Elizabeth, M.B., D.Sc. Mabel Webb Research Scholar, UC. [1; chemical studies of tissue, with S. B. Schryver; 1904]. Jenner Research Student at the Lister Institute, 1908-12.

"Marcet, Jane. [1; general, textbook; 1806].

Marshall, Dorothy. UC. [4; latent heat studies, including 1 with Sir Wm Ramsay and 1 with E. H. Griffiths; 1896-97].

"Micklethwait, Frances Mary Gore. RCS. [9; mainly organic synthesis; 1902-05].

†RAISIN, Catherine Alice, B.Sc., D.Sc. UC. [1; mineral analysis, with T. G. Bonney; 1894].

$\nmid$ Renouf, Nora. Research Laboratory, Pharmaceutical Society. [1; organic, with A. W. Crossley; 1905].

"Somerville, Mary Fairfax Grieg. [3; including 1 monograph; 1826-46].

Sowton, (Miss) S. C. M. University of London and St Mary's Hospital. [4; physiological chemistry, with A. D. Waller, 1896-03]. Two more papers in 1910 from the University of Liverpool and the State University, Utrecht.

"Whiteley, Martha Annie, D.Sc. RCS. [6; including 1 with H. Crompton; 1895-04].

100 Miss Lucy Halcrow and E. Frankland, 'On the action of air upon peaty water', Journal of the Chemical Society, Transactions, (1880), 37, pp. 506-17. 


\section{Other locations}

Clarke, Rosalind, B.A. Demonstrator in chemistry, Queen's College, Galloway. [2; including 1 on Grignard syntheses with A. Senior and P. C. Austin, and 1 on laboratory procedures with Senior; 1905]. Published 3 more papers in the period up to 1922, including 1 from Bonn University in 1908.

Fitzgerald, Mabel Purefoy. Oxford. 11; physiological chemistry, with J. S. Haldane; 1905].

${ }^{*}$ Fortey, Emily C., B.Sc. University College, Bristol. [14; including 8 with S. Young and 2 with A. Richardson ; 1896-03].

Goodson, Ethel Elizabeth, B.Sc. University of Leeds. [1; solubility studies, with H. M. Dawson; 1904].

GreEN, Wilhelmina M. [1; analytical; 1885].

†Hibbert, Eva. Municipal School of Technology, Manchester. [4; with E. Knecht, analytical methods/organic synthesis; 1903-05].

Hooker, Emma Jane. Rottingdean, nr Brighton. [1; inorganic/technical; 1808].

Johnston, Erta J. University College, Dundee. [1; analytical/public health chemistry, with T. Carnelley; 1888].

Johnston, Margaret Neill. Yorkshire College, Leeds. [1; water analysis, with C. L. Kennedy and T. E. Thorpe; 1881].

KeLly, Agnes. Mineralogical Laboratory, Oxford. [1; analytical; 1990].

KenNEDY, Catherine Lucy. Yorkshire College, Leeds. [1; water analysis, with M. N. Johnston and T. E. Thorpe; 1881].

Lloyd, Emily Jane. Mason Science College, Birmingham. [1; osmotic pressure studies; 1889]. Lloyd was the first woman Associate of the Institute of Chemistry, passing the required examination in $1892 .{ }^{101}$

Marshall, Margaret Henrietta. Edinburgh? [1; general; 1851].

†Moody, Agnes Marion, MA, B.Sc. University of St Andrews. [1; sugar chemistry, with J. C. Irvine; 1905].

†Newbigin, Marion Isabel, B.Sc., D.Sc. Lecturer in biology, extra-mural School of Medicine for Women, Edinburgh and Royal College of Physicians, Edinburgh. [6; biochemical, including 1 joint paper; 1896-99]. Had second career as an eminent geographer; was editor of the Scottish Geographical Magazine, 1902-34, and author of more than 25 monographs. ${ }^{102}$

Passavant, Laura Maude. Brown Scholar, Yorkshire College, Leeds. [1; specific volume studies; 1881].

SEward, Margaret (Mrs McKillop), MA. Dover College. [3; solution equilibria, with W. H. Pendlebury; 1889-95]. Was later lecturer in chemistry, Women's Department, King's College, London.

†SMITH, Alice Emily, B.Sc. University College, Bangor and Owens College, Manchester. [4; including 3 with W. H. Perkins, Jr and 1 with K. J. P. Orton; 1902-05].

101 Pilcher, op. cit. (72), p. 114.

102 See 'Marion Isabel Newbigin', obituary in the Scottish Geographical Magazine, (1934), 50, pp. 331-3. 
TAYLOR, Clara Millicent, B.Sc. University College, Bristol. [2; organic synthesis, including 1 with F. E. Francis; 1903-04]. Was later lecturer in chemistry, Ladies College, Cheltenham; research activity continued into the 1920 s.

Thresh, May. County Technical Laboratory, Chelmsford. [1; mineral analysis; 1902]. WaLter, Lavinia Edna. [1; organic synthesis; 1895].

"WILLIams, Katherine Isabella, B.Sc. University College, Bristol. [5; including 3 on food analysis, and 2 with Sir Wm Ramsay; 1886-04].

Appendix 2. Number of papers per year authored or co-authored by women $1900-10^{a}$

\begin{tabular}{cccccc}
\hline \hline & Cambridge & $\begin{array}{c}\text { Metropolitan } \\
\text { colleges }\end{array}$ & $\begin{array}{c}\text { Other English } \\
\text { colleges and } \\
\text { universities }\end{array}$ & $\begin{array}{c}\text { Scortish } \\
\text { colleges and } \\
\text { universities }\end{array}$ & Total \\
\hline 1900 & 2 & 2 & 4 & 1 & 9 \\
1901 & 2 & 1 & - & - & 3 \\
1902 & - & 6 & 5 & - & 11 \\
1903 & 4 & 7 & 6 & - & 17 \\
1904 & 5 & 6 & 7 & 2 & 24 \\
1905 & 3 & 13 & 7 & 1 & 23 \\
1906 & 3 & 12 & 12 & 2 & 25 \\
1907 & 3 & 8 & 9 & 6 & 36 \\
1908 & 2 & 23 & 19 & 8 & 47 \\
1909 & 2 & 14 & 11 & & \\
1910 & 4 & 24 & & & 2 \\
\hline \hline
\end{tabular}

a Data were obtained by counting papers by women listed in the London Chemical Society decennial indices, 1893-1912. ${ }^{103}$ Communications in the Proceedings section of the Journal of the Chemical Society have been excluded if they were later followed up by full papers on the same material in the Transactions section. However, there are a few cases where Proceedings articles are the only records of the work, and these have generally been included here. A similar procedure has been followed in the case of other journals. Total number of publications for the period are indicated graphically in Figure 1.

103 A Collective Index of the Transactions, Proceedings and Abstracts of the Chemical Society, 1873-1912, 4 vols., London [n.d.]. Work published in non-British journals is covered by the Abstracts sections of this Index. 